\title{
PENGARUH KARBON AKTIF KULIT PISANG PUTRI PADA LIMBAH AMMONIA
}

\author{
Surya Hatina $^{1)^{*}}$, Eddyanto Winoto ${ }^{1)}$, Ida Febriana ${ }^{2)}$, Antoni ${ }^{1)}$ \\ ${ }^{1)}$ Program Studi Teknik Kimia, Fakultas Teknik, Universitas Tamansiswa Palembang \\ Jalan Tamansiswa No.261 Palembang \\ ${ }^{2)}$ Jurusan Teknik Kimia, Politeknik Negeri Sriwijaya \\ "email: surya@unitaspalembang.ac.id
}

\begin{abstract}
Abstrak
Penelitian yang telah dilakukan ini bertujuan untuk mengetahui temperatur karbonisasi terbaik, mengetahui luas permukaan terbaik, mengetahui waktu absrorbsi dan untuk mengetahui kandungan ammonia dari limbah setelah dilakukan proses absorbsi dengan karbon aktif kulit pisang putri. Karbon aktif dari limbah kulit pisang putri digunakan untuk mengurangi kadar amonia yang tinggi. Variabel yang digunakan dalam penelitian ini antara lain adalah temperatur karbonisasi $\left(250^{\circ} \mathrm{C}, 300{ }^{\circ} \mathrm{C}\right.$ dan $\left.350^{\circ} \mathrm{C}\right)$, luas permukaan $(1 \mathrm{~cm}$ dan $2 \mathrm{~cm})$ dan waktu absorbsi $(10$ jam dan 12 jam). Dari hasil analisa yang didapatkan bahwasannya karbon aktif yang dibuat dari kulit pisang putri mampu menurunkan kadar ammonia pada limbah cair secara signifikan. Dari 13 sampel yang telah dilakukan, didapatkan bahwa sampel no 10 dengan parameter $350{ }^{\circ} \mathrm{C}$, luas permukaan $1 \mathrm{~cm}$ dan waktu absorbsi 10 jam memiliki hasil terbaik dibandingkan dengan sampel lainnya. Dimana kandungan ammonia nya menjadi 0,1, sedangkan ammonia sebelum absorbsi adalah 1,2, kandungan COD dari 84,32\% menjadi $5,02 \%$ dan mengalami penurunan $\mathrm{pH} 12,4$ menjadi 7,7.
\end{abstract}

Kata kunci : Karbon Aktif, Kulit Pisang Putri, Ammonia, Limbah Cair.Absorbsi

\section{PENDAHULUAN}

Negara Indonesia merupakan negara agrikultur yang memiliki kekayaan alam yang luas khususnya dibidang pertanian dan perkebunan. Oleh karena itu tidak mengherankan kalau Indonesia memberikan kontribusi yang tinggi terhadap limbah-limbah hasil pertanian, seperti halnya limbah kulit pisang.

Limbah kulit pisang adalah contoh biomassa yang tadinya derivatif dari pisang yang telah diambil kulit nya. Limbah ini sangat dimungkinkan untuk didapatkan dalam jumlah yang besar. Mengingat Indonesia merupakan salah satu negara yang memproduksi pisang dalam jumlah terbesar. Khususnya di Indonesia, pisang merupakan produksi terbesar ketiga setelah padi dan singkong. Produksi buah pisang dalam setahun berkisar 6,7 juta matrik ton.

Pemanfaatan kulit pisang belum banyak dilakukan oleh masyarakat, mereka berasumsi bahwasannya kulit pisang hanya limbah yang dapat menyebabkan lingkungan menjadi tercemar. Namun ada juga beberapa kalangan masyarakat yang memanfaatkan kulit pisang sebagai pakan ternak domestik.

Limbah kulit pisang seperti ini umumnya langsung dibakar begitu saja tanpa disertai pengolahan dan pembakaran limbah kulit pisang ini juga bisa mengganggu kesehatan. Akibat negatif yang bisa terjadi jika limbah kulit pisang dibiarkan begitu saja tanpa adanya proses terlebih dahulu dan langsung dibakar adalah kelembapan dari kulit pisang akan mempengaruhi partikel partikel yang tidak terbakar. Partikel - partikel dari kulit pisang yang tidak terbakar tersebut terbang dibawa ke udara. Hal ini bisa menyebabkan hidrokarbon yang berbahaya bagi kesehatan masyarakat. Kenyataanya bahwa kulit pisang mengandung $50.6 \%$ karbon per 100 gram beratnya. 
Limbah kulit pisang yang tidak dimanfaatkan dapat dijadikan karbon aktif, dimana hasil yang didapatkan untuk karbonisasinya mencapai $96,56 \%$. Penelitian ini telah dilakukan oleh Biosciences Institute menyatakan bahwasannya limbah kulit pisang mampu menarik unsur logam-logam berat yang terkandung di dalam air limbah (Mirsa, 2013).

Pada umumnya kulit pisang memiliki warna yang berbeda, ada kulit pisang berwarna hijau, hijau kekuningan dan kuning. Maka komponen yang terdapat pada kulit pisang berbeda. Umumnya komponen yang terdapat didalam kulit pisang terdiri dari lemak, serat kasar, protein, kadar air, kadar abu, karbohidrat, dan lainnya. Selain itu juga, Kulit pisang memiliki kandungan pati $0.98 \%$. Kandungan pati ini sebagai bahan baku pembuatan bioplastik (A. Munawaroh, 2015).

Berdasarkan hasil analisis Van Soest dan Tanin yang dilakukan pada kulit pisang didapatkan bahwa kandungan lignin, selulosa dan hemiselulosa sebesar 20,21\%, 9,525\%, 7,48\%. Unsur lignoselulosa yang ada di dalam kulit pisang ini menunjukkan kalau kulit pisang mengandung banyak karbon. Hal ini diungkapkan Manocha bahwasannya material yang mengandung lignoselulosa merupakan material yang kaya akan karbon. Kandungan karbon dalam material tersebut berkisar antara $35 \%-40 \%$. Senyawa inilah yang dapat menjadikan kulit pisang dijadikan dalam pembuatan karbon aktif

Jadi, limbah kulit pisang bisa dimanfaatkan sebagai bahan utama dalam pembuatan karbon aktif. Kebutuhan dari karbon aktif sebagai benda penyerap sangat meningkat sekarang ini, khususnya dalam pengolahan limbah. Pemanfaatan kulit limbah pisang khususnya pisang tanduk sebagai bahan baku karbon aktif juga telah dilakukan penelitiannya. Dimana menggunakan variasi konsentrasi aktivator $\mathrm{NaCl}$ (Muhrinsyah,2020). Dan semakin lama waktu aktivasi dalam pembuatan karbon aktif, kandungan kadar air juga cenderung meningkat. Selain itu semakin besar luas permukaan karbon aktif maka semakin tinggi adsorpsinya (Rully Masriatini, 2017).

Karbon aktif adalah suatu padatan berpori yang memiliki unsur karbon 85 - $95 \%$, dapat dihasilkan dengan melakukan pemanasan pada suhu tinggi dan diperoleh luas permukaan yang sangat besar, dimana ukurannya antara $300-2000 \mathrm{~m} 2 /$ gr. Luas permukaan yang besar dari struktur dalam pori-pori karbon aktif dapat terus dikembangkan, struktur ini memberikan kemampuan karbon aktif menyerap (adsorb) gas-gas dan uap-uap dari gas dan juga dapat menguraikan zat-zat dari liquida(Kirk-Othmer, 1992).

Kandungan air yang ada dalam kulit pisang cukup besar yakni bisa mencapai 68,90\%, selain itu kandungan terbesar lainnya adalah karbohidrat yaitu sebesar $18,50 \%$. Dan sisanya adalah protein, zat besi dan unsur lainnya.

Berikut adalah komposisi lengkap unsur-unsur kimia per 100 gram kulit pisang :

Tabel 1. Komposisi Kimia Kulit Pisang

\begin{tabular}{|l|l|}
\hline \multicolumn{1}{|c|}{ Zat Gizi } & \multicolumn{1}{c|}{ Kadar (\%) } \\
\hline Air (g) & 68.90 \\
\hline Karbohidrat (g) & 18.50 \\
\hline Lemak (g) & 2.11 \\
\hline Protein (g) & 0.32 \\
\hline Kalsium (mg) & 715 \\
\hline Fosfor (mg) & 117 \\
\hline Zat Besi (mg) 1.60 & Zat Besi (mg) 1.60 \\
\hline Vitamin B (mg) 0.12 & Vitamin B (mg) 0.12 \\
\hline Vitamin C (mg) 17.50 & Vitamin C (mg) 17.50 \\
\hline
\end{tabular}

Balai penelitian dan pengembangan Industri, Surabaya, Jatim 
Limbah cair ataupun dikenal dengan air limbah merupakan air yang sudah tidak terpakai lagi dan merupakan hasil buangan berbagai kegiatan yang dilakukan manusia untuk memenuhi kebutuhan hidup sehari-hari. Seiring dengan bertambahnya jumlah populasi penduduk dengan segala kebutuhannya, maka bisa dipastikan meningkatnya jumlah air limbah. Pada umumnya limbah cair dibuang ke dalam sungai, tanah, laut ataupun danau. Jika air limbah yang dibuang terlalu berlebihan dapat merusak lingkungan, serta dapat menimbulkan pencemaran dan merusak kesehatan masyarakat. Dan tak dapat dipungkiri juga bahwasannya pihak industri merupakan salah satu penyokong tingginya jumlah air limbah. Yang mana disebabkan karena pengolahan dan penanganan limbah tersebut yang tidak menjadi perhatian yang serius,. Contohnya untuk limbah ammonia.

Kandungan ammonia yang ada di dalam limbah dapat menyebabkan alergi, mutagen, teratogen bahkan karsinogen pada makhluk hidup khususnya manusia yang bisa terjadi pada kulit, pernapasan atau pencernaan. Kandungan ammonia adalah salah satu zat pencemar yang ada di dalam kandungan air limbah dan biasanya terkontaminasi dengan air bersih yang ada disekitar masyarakat penduduk. Karena hal inilah, proses penjernihan air limbah ammonia perlu adanya penyerapan dengan menggunakan karbon aktif

Kandungan ammonia pada limbah cair tahu mengalami penurunan menjadi $24,10 \mathrm{mg} / \mathrm{l}$ dengan waktu kontal 3 menit, 22,63 mg/l waktu kontak 5 menit dan 19,9 mg/l dengan waktu kontak 7 menit, dan penurunan yang terbesar adalah pada waktu kontak 7 menit yakni menjadi 10,67 mg/l (Lina Roesiani, 2015)

Berdasarkian penelitian Suyata (2009), bahwasannya kandungan ammonia limbah tahu dapat dikecilkan dengan memvariasikan waktu kontak dengan karbon aktif. Dimana penelitian ini menggunakanan waktu kontak 1 menit, 10 menit, 30 menit, 45 menit, 60 menit, 90 menit dan 120 menit. Dan didapatkan hasil dengan waktu kontak yang paling maksimal dalam menurunkan kadar ammonia adalah 30 menit dengan 64,69 \% penurunan. Selain itu juga Suyata memvariasikan Ph yakni 4,5,6,7,8,9 dan 10. Didapatkan juga kalau kondisi pH basa atau asam karbon aktif masih efektif dalam menurunkan ammonia, dan ph terbaik adalah 7

Proses adsorpsi yang memakai karbon aktif merupakan proses penyerapan yang paling baik dibandingkan jika menggunakan metode kimia atau metode fisik lainnya dalam mengolah air limbah. Dikarenakan mampu menyerap secara efektif. Tetapi karbon aktif yang bisa kita dapatkan secara komersil membutuhkan biaya yang cukup mahal dikarenakan menggunakan bahan baku yang tidak dapat diperbahari seperti halnya batubara (Tan et al., 2008).

Ukuran karbon aktif yang tidak seragam dapat mempengaruhi luas permukaan pori karbon aktif. Dimana semakin besar ukuran pori karbon aktif, akan semakin banyak pula partikel yang teradsorbsi (Eddyanto Winoto, 2020)

Dalam penelitian ini digunakan jenis kulit pisang putri sebagai bahan utama pembuatan karbon aktif dalam mengurangi kandungan ammonia.

\section{METODOLOGI PENELITIAN}

Variabel yang digunakan pada penelitian ini adalah :

1. Variabel Tetap : Konsentrasi Aktivator yang digunakan adalah $\mathrm{NaoH} 0,1 \mathrm{M}$

2. Variabel berubah : Temperatur dan Luas Permukaan dan Waktu Absorsi 


\begin{tabular}{|c|c|c|c|}
\hline No Sampel & $\begin{array}{c}\text { Temperatur } \\
\left({ }^{\mathbf{C}} \mathbf{C}\right)\end{array}$ & $\begin{array}{c}\text { Luas } \\
\text { Permukaan } \\
(\mathbf{c m})\end{array}$ & $\begin{array}{c}\text { Waktu Abs } \\
(\mathbf{j a m})\end{array}$ \\
\hline Sampel 1 & \multicolumn{2}{|c|}{ Sampel Limbah Ammonia 1,2 M } \\
\hline Sampel 2 & 250 & 1 & 10 \\
\hline Sampel 3 & 250 & 1 & 12 \\
\hline Sampel 4 & 250 & 2 & 10 \\
\hline Sampel 5 & 250 & 2 & 12 \\
\hline Sampel 6 & 300 & 1 & 10 \\
\hline Sampel 7 & 300 & 1 & 12 \\
\hline Sampel 8 & 300 & 2 & 10 \\
\hline Sampel 9 & 300 & 2 & 12 \\
\hline Sampel 10 & 350 & 1 & 10 \\
\hline Sampel 11 & 350 & 1 & 12 \\
\hline Sampel 12 & 350 & 2 & 10 \\
\hline Sampel 13 & 350 & 2 & 12 \\
\hline
\end{tabular}

Paramater yang dianalisa adalah Ammonia, COD, dan $\mathrm{pH}$

Peralatan dan bahan yang digunakan dalam penelitian ini antara lain :

1. Karbon Aktif Kulit Pisang Putri.

2. Oven

3. Gelas Kimia

4. Timbangan Digital

5. Batang Pengaduk

6. Ayakan mesh

7. Furnace

8. Nampan Tray

9. Gelas Ukur

Bahan yang digunakan :

1. Kulit Pisang Putri

2. Limbah Ammonia $1,2 \mathrm{M}$

3. $\mathrm{NaOH} 0,1 \mathrm{M}$

4. Aquades 


\section{Blok Diagram Penelitian}

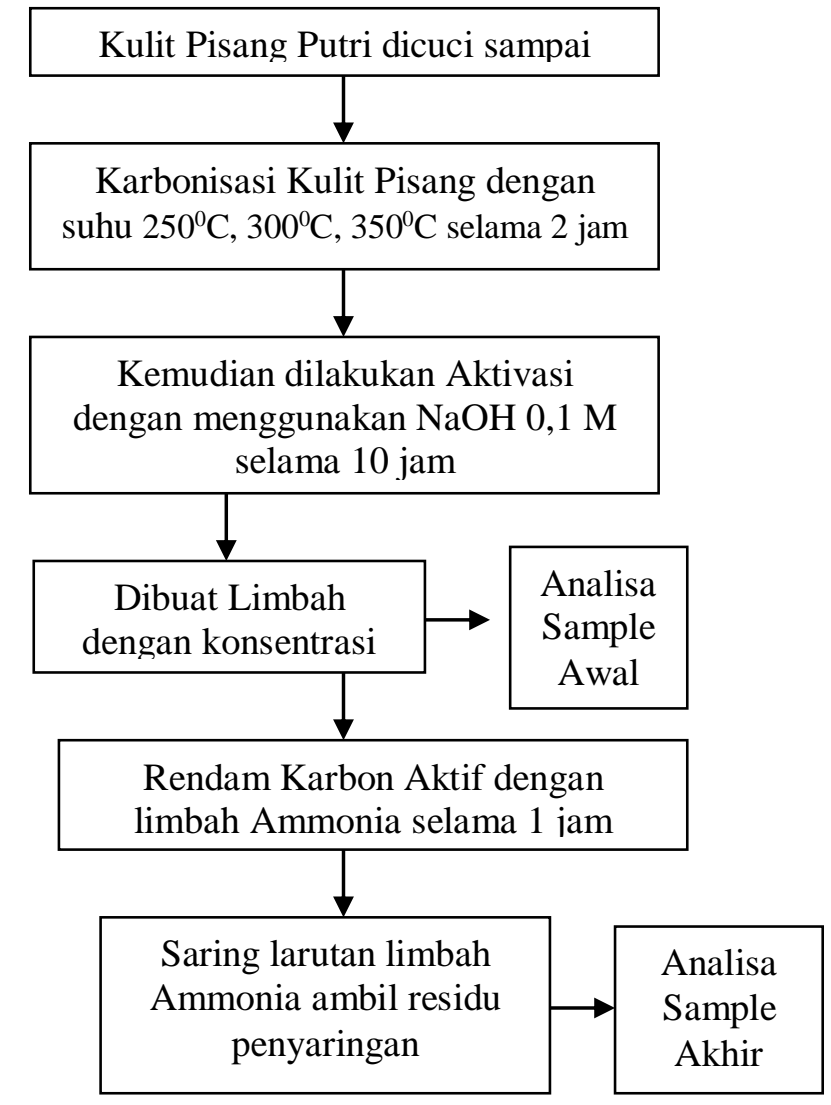

Gambar 1. Proses Pengurangan ammonia dengan menggunakan karbon aktif dari kulit pisang Putri

\section{Pembuatan Karbon Aktif}

1. Kulit Pisang Putri di karbonisasi dengan furnace pada suhu $250^{\circ} \mathrm{C}, 300^{\circ} \mathrm{C}$, dan $350^{\circ} \mathrm{C}$ selama 2 jam

2. Setelah dibakar lalu diaktivasi dengan larutan $\mathrm{NaOH}$ dengan konsentrasi $0,1 \mathrm{M}$ tujuannya untuk membuka pori dari C Aktif Kulit Pisang Putri.

3. Kemudian ditumbuk dan diayak sampai dapat ukuran $1 \mathrm{~cm}, 2 \mathrm{~cm}, 3 \mathrm{~cm}$

Prosedur Pembuatan Limbah Ammonia 1,2 M

1. Pipet Ammonia $36 \%$ sebanyak $7,79 \mathrm{~mL}$

2. Masukan kedalam Labu Ukur $100 \mathrm{~mL}$.

3. Tambahkan Aquades hingga volume $100 \mathrm{~mL}$

4. Didapat larutan $1,2 \mathrm{M}$

Prosedur Analisa Ammonia

1. Pipet $100 \mathrm{~mL}$ sample kedalam beaker glass $1000 \mathrm{~mL}$.

2. Tambahkan $300 \mathrm{~mL}$ Aquades kedalam beaker glass $1000 \mathrm{~mL}$.

3. Tambahkan Buffer Borak $25 \mathrm{~mL}$ sehingga pH menjadi 4,2.

4. Jadikan $\mathrm{pH}$ larutan menjadi 9,5 dengan menambahkan $\mathrm{H} 2 \mathrm{SO} 4$.

5. Lakukan destilasi sampai volume destilat $200 \mathrm{~mL}$.

6. Tambahkan $50 \mathrm{~mL}$ Asam Borak dan Indikator mix warna larutan destilat ungu tua

7. Titrasi dengan $\mathrm{H} 2 \mathrm{SO} 40,02 \mathrm{~N}$ sampai warna ungu. 
8. Lakukan pengujian juga terhadap blanko.

$$
\mathrm{NH} 3 \mathrm{~N}=\frac{1000 \mathrm{x}(\text { V Sample }- \text { V Blanko }) \times \mathrm{N} \mathrm{H} 2504 \mathrm{x} 14 \mathrm{xFP}}{\text { V Sample }}
$$

\section{HASIL DAN PEMBAHASAN}

Berdasarkan hasil analisa terhadap variabel percobaan didapatkan data sebagai berikut :

Tabel 3. Data Hasil Penelitian untuk Analisa Ammonia, COD dan pH

\begin{tabular}{|c|c|c|c|}
\hline \multirow{2}{*}{ Sampel } & \multicolumn{3}{|c|}{ Hasil Analisa } \\
\cline { 2 - 4 } & $\begin{array}{c}\text { Ammonia } \\
(\mathrm{M})\end{array}$ & $\mathrm{COD}(\%)$ & $\mathrm{pH}$ \\
\hline Sampel 1 & 1,2 & 84,32 & 12,4 \\
\hline Sampel 2 & 0,080 & 10,54 & 8,4 \\
\hline Sampel 3 & 0,075 & 8,32 & 8,1 \\
\hline Sampel 4 & 0,070 & 8,54 & 8,3 \\
\hline Sampel 5 & 0,060 & 7,42 & 8,2 \\
\hline Sampel 6 & 0,040 & 8,33 & 8,3 \\
\hline Sampel 7 & 0,030 & 7,20 & 8,4 \\
\hline Sampel 8 & 0,020 & 6,66 & 8,0 \\
\hline Sampel 9 & 0,015 & 5,12 & 7,9 \\
\hline Sampel 10 & 0,010 & 5,02 & 7,7 \\
\hline Sampel 11 & 0,045 & 7,77 & 8,3 \\
\hline Sampel 12 & 0,040 & 9,45 & 8,5 \\
\hline Sampel 13 & 0,035 & 8,88 & 8,4 \\
\hline
\end{tabular}

Pengaruh Temperatur, Ukuran Partikel, dan Waktu Absorbsi Karbon Aktif terhadap kadar Ammonia

Pengaruh Temperatur, Ukuran Partikel, dan Waktu Absorbsi Karbon Aktif terhadap kadar Ammonia dari beberapa Sampel didapat data sebagai berikut 
Tabel 4. Hasil Analisa Kadar Ammonia

\begin{tabular}{|c|c|}
\hline Sampel & Ammonia (M) \\
\hline Sampel 1 & 1,2 \\
\hline Sampel 2 & 0,080 \\
\hline Sampel 3 & 0,075 \\
\hline Sampel 4 & 0,070 \\
\hline Sampel 5 & 0,060 \\
\hline Sampel 6 & 0,040 \\
\hline Sampel 7 & 0,030 \\
\hline Sampel 8 & 0,020 \\
\hline Sampel 9 & 0,015 \\
\hline Sampel 10 & 0,010 \\
\hline Sampel 11 & 0,045 \\
\hline Sampel 12 & 0,040 \\
\hline Sampel 13 & 0,035 \\
\hline
\end{tabular}

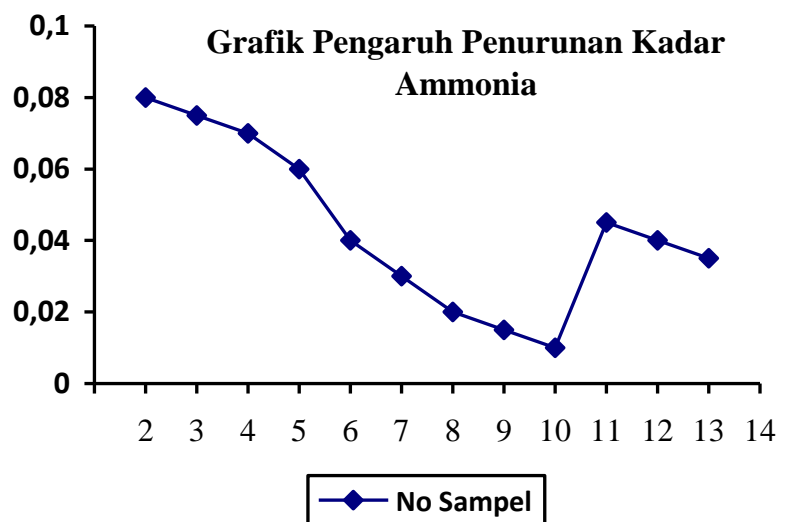

Gambar 2. Grafik Pengaruh Nilai Ammonia

Berdasarkan grafik diatas maka dapat dilihat bahwa kadar Ammonia terendah terdapat pada sample no . 10 karena temperaturnya maksimal $350^{\circ} \mathrm{C}$ merupakan suhu terbaik dari proses karbonisasi dan pengarangannya sempurna sehingga karbon aktif dapat menyerap banyak ammonia. Luas permukaan karbon aktif $1 \mathrm{~cm}$ sehingga semua penyerapan karbon aktif dapat menjadi lebih baik 
Pengaruh Temperatur, Ukuran Partikel, dan Waktu Absorbsi Karbon Aktif terhadap kadar COD

Tabel 5. Hasil Analisa Kadar COD

\begin{tabular}{|c|c|}
\hline Sampel & COD $(\%)$ \\
\hline Sampel 1 & 84,32 \\
\hline Sampel 2 & 10,54 \\
\hline Sampel 3 & 8,32 \\
\hline Sampel 4 & 8,54 \\
\hline Sampel 5 & 7,42 \\
\hline Sampel 6 & 8,33 \\
\hline Sampel 7 & 7,20 \\
\hline Sampel 8 & 6,66 \\
\hline Sampel 9 & 5,12 \\
\hline Sampel 10 & 5,02 \\
\hline Sampel 11 & 7,77 \\
\hline Sampel 12 & 9,45 \\
\hline Sampel 13 & 8,88 \\
\hline
\end{tabular}

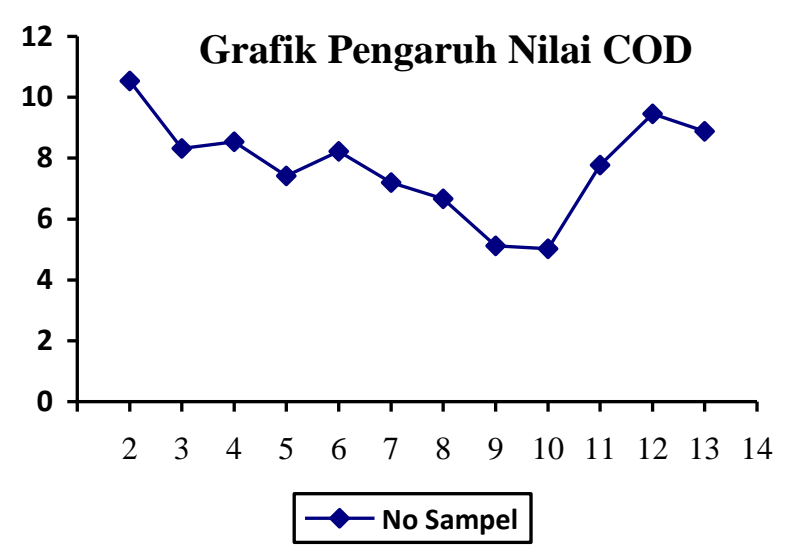

Gambar 3. Pengaruh Nilai COD

Pada gambar 3 terlihat bahwa sampel no 10 memiliki nilai COD yang paling rendah karena nilai Ammonia pada sample sedikit sehingga nilai COD menjadi rendah. Selain itu dengan hasil karbonisasi yang sempurna menyebabkan COD pada sampel diserap oleh karbon aktif secara lebih baik. 


\section{Pengaruh Temperatur, Ukuran Partikel, dan Waktu Absorbsi Karbon Aktif terhadap nilai pH}

Tabel 6. Hasil Analisa pH

\begin{tabular}{|c|c|}
\hline Sampel & $\mathrm{pH}$ \\
\hline Sampel 1 & 12,4 \\
\hline Sampel 2 & 8,4 \\
\hline Sampel 3 & 8,1 \\
\hline Sampel 4 & 8,3 \\
\hline Sampel 5 & 8,2 \\
\hline Sampel 6 & 8,3 \\
\hline Sampel 7 & 8,4 \\
\hline Sampel 8 & 8,0 \\
\hline Sampel 9 & 7,9 \\
\hline Sampel 10 & 7,7 \\
\hline Sampel 11 & 8,3 \\
\hline Sampel 12 & 8,5 \\
\hline Sampel 13 & 8,4 \\
\hline
\end{tabular}

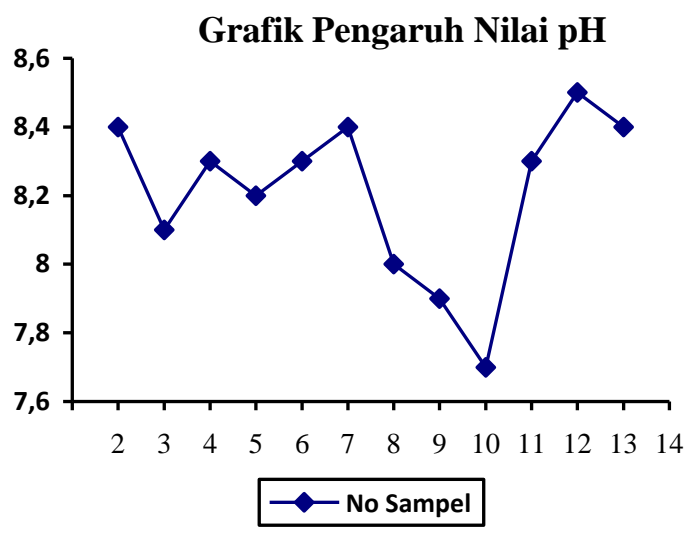

Gambar 4. Pengaruh Nilai $\mathrm{pH}$

Gambar diatas menunjukkan bahwa nilai $\mathrm{pH}$ pada sample. $\mathrm{pH}$ terendah terdapat pada sample 10 sebesar 7,7. Hal ini disebabkan karena nilai Ammonia pada sample rendah sehingga $\mathrm{pH}$ hampir mendekati netral.

Data tabel hasil analisa di atas menunjukkan bahwa ammonia yang awalnya konsentrasi 1,2 $\mathrm{M}$ berkurang secara signifikan dikarenan adanya proses adsorbsi oleh karbon aktif. Selain itu untuk kadar COD juga mengalami penurunan yang signifikan yakni lebih dari $80 \%$ nilai penurunannya yang tadinya kandungan COD 84,32\% menjadi lebih kecil dari 10\%, dan analisa $\mathrm{pH}$ juga mengalami penurunan yang disebabkan proses adsorbsi dari karbon aktif kulit pisang putr dan $\mathrm{pH}$ limbah mendekati normal 
Dari hasil analisa sebanyak 13 sampel didapatkan komposisi terbaik pada sampel no 13 dengan temperatur $350^{\circ} \mathrm{C}$, luas permukaan $1 \mathrm{~cm}$ dan waktu adsorbsi selama $10 \mathrm{jam}$. Dimana hasil analisa untuk kadar ammonia $0,01 \mathrm{M}$, nilai COD 5,02\% dan $\mathrm{pH} 7,1$

\section{KESIMPULAN}

Dari beberapa variabel yang telah digunakan dalam penelitian ini maka dapat disimpulkan bahwa sampel terbaik yaitu sampel 10 (Temperatur $350^{\circ} \mathrm{C}$, luas permukaan $1 \mathrm{~cm}$, dan waktu absorbsi 10 jam) dengan kadar Ammonia sebesar 0,010\%, kadar COD 5,2\% dan pH 7,7. Untuk proses karbonisasi terbaik dilakukan pada temperatur $350^{\circ} \mathrm{C}$ dan waktu aktivasi terbaik yaitu 10 jam, jika lebih lama dikhawatirkan karbon aktif akan terkontaminasi. Semakin kecil ukuran partikel, maka penyerapan karbon aktif semakin baik. Dan Limbah yang diserap karbon aktif kulit pisang putri telah sesaui dengan Permen LH 2014 tentang Baku Mutu Air Limbah

\section{DAFTAR PUSTAKA}

Balai Penelitian dan Pengembangan Industri, 1982, Komposisi Kimia Kulit Pisang, Surabaya, Jawa Timur.

Eddyanto Winoto, dkk. 2020. "Pemanfaatan Karbon Aktif Dari Serbuk Kayu Merbau Dan Tongkol Jagung Sebagai Adsorben Untuk Pengolahan Limbah Cair AAS”, Jurnal Redoks Volume 5 No. 1, Hal 32-46.

Kirk-Othmer, 1992, "Encyclopedia Chemical Technology 2nd ed, vol 12", John Willy and Sons.

Lina Roesiani 2015, Program Studi Kesehatan Masyarakat Fakultas Ilmu Kesehatan Universitas Muhammadiyah Surakarta.

Mirsa Restu Adinata, 2013. "Pemanfaatan Limbah Kulit Pisang Sebagai Karbon Aktif". Skripsi, Fakultas Teknologi Industri Universitas Pembangunan Nasional "Veteran" Surabaya.

Munawaroh. 2015. "Pemanfaatan Tepung Kulit Pisang (Musa Paradisiaca) Dengan Variasi Penambahan Gliserol Sebagai Bahan Alternatif Pembuatan Bioplastik Ramah Lingkungan”. Artikel Publikasi Ilmiah. Surakarta : Universitas Surakarta.

Muhrinsyah Fatimura, dkk, 2020, "Pemanfaatan Limbah Kulit Pisang Menjadi Karbon Aktif Dengan Variasi Konsentrasi Aktivator NaCl”. Jurnal Redoks Vol 5 No 2, Hal 87-95.

Permen LH 2014 Baku Mutu Air Limbah .

Rully Masriatini, 2017, "Pembuatan Karbon Aktif Dari Kulit Pisang”, Jurnal Redoks Volume 2 No. 1. Hal 53-57.

Suyata I. 2009. Penurunan Kadar Amonia, Nitrit, dan Nitrat Limbah Cair Industri Tahu menggunakan Arang Aktif dari Ampas Kopi . Jurnal Molekul. Vol. 4. No. 2. November, 2009 : 105- 114.

Tan, I. A. W., Ahmad, A. L., \& Hameed, B. H., 2008. Preparation of activated carbon from coconut husk: Optimization study on removal of 2,4,6- trichlorophenol using response surface methodology. Journal of Hazardous Materials, 153(1-2), 709-717. Doi:10.1016/j.jhazmat.2007.09.014 